\title{
Konsep Rencana Pengembangan Lansekap Subak Sebagai Kawasan Agrowisata Berkelanjutan
}

\author{
LURY SEVITA YUSIANA ${ }^{1 *}$, NI NYOMAN ARI MAYADEWI² \\ ${ }^{1}$ Program Studi Arsitektur Pertamanan, Fakultas Pertanian, Universitas Udayana, JI. PB \\ Sudirman Denpasar, Indonesia \\ 2 Program Studi Agroekoteknologi, Fakutas Pertanian, Universitas Udayana, Jl. PB \\ Sudirman Denpasar, Indonesia \\ *E-mail: lury.yusiana@unud.ac.id
}

\section{ABSTRACT \\ Concept of Subak Landscape Development Plan As a Sustainable Agrotourism Area}

Subak is one of the world cultural heritage. However, the rapid development of tourism in Bali threatens the existence of the subak. The high price of land becomes unequal to farmers' income from the agricultural sector. Agricultural sector began to be abandoned and the existence of subak began to disappear. To reduce these threats, it is necessary to develop agricultural areas by focusing on the productivity of the performances that produce quality commodities and the development of agricultural landscape potential as a tourist destination. This study aims to plan the concept for the development of agricultural and subak areas as the motor of the agricultural sector to obtain economic opportunities through the tourism sector. The research method is done by analyzing agriculture sector through subak component (Windia, 2013) and analyzing the plan of arrangement of tourist landscape through tourism development component (Inskeep, 1991). The final product of this research is the concept of sustainable agro-tourism plan on the subak landscape.

Keywords: subak, agrotourism, tourism landscape planning

\section{Pendahuluan}

Pertanian di Bali dengan sawah berteras mampu menarik minat wisatawan untuk berkunjung dan menikmati indahnya lansekap pertanian. Hal ini pada akhirnya mendorong keinginan investor untuk menanamkan modal besar pada lokasi pertanian di Bali sebagai obyek wisata. Berkembangnya sebuah obyek wisata menuntut adanya ketersediaan sarana dan prasarana serta fasilitas-fasilitas lain untuk kenyamanan wisatawan. Dengan demikian, investasi pada berbagai sektor menjadi meningkat dan pembangunan menjadi tidak terbendung. Hal ini memicu peningkatan nilai lahan secara ekonomi. Tingginya harga lahan menjadi tidak sebanding dengan pendapatan petani dari sektor pertanian. Memicu masyarakat untuk menjual lahan dan/atau menyewakan lahan termasuk lahan pertanian. Hasil yang diperoleh mampu memenuhi kebutuhan ekonomi masyarakat. Sektor pertanian mulai ditinggalkan dan eksistensi subak mulai hilang. Untuk mengurangi ancaman 
tersebut, maka diperlukan pengembangan kawasan pertanian dengan menitikberatkan pada produktivitas pertanian yang menghasilkan komoditi berkualitas dan pengembangan potensi lansekap pertanian sebagai destinasi wisata. Konsep ini menitikberatkan pertanian sebagai fokus utama dan wisata menjadi dampak positif bagi pengembangan ekonomi pertanian.

Penelitian ini bertujuan untuk merencanakan konsep bagi pengembangan kawasan pertanian dan subak sebagai motor penggerak sektor pertanian untuk memperoleh peluang ekonomi melalui sektor pariwisata. Produk akhir penelitian ini berupa konsep atau gagasan yang menjadi dasar dalam pengembangan agrowisata bagi subak di Bali.

\section{Metode}

Kegiatan penelitian dilaksanakan selama 6 bulan dimulai bulan April hingga September 2016. Penelitian dilakukan pada Subak dengan studi kasus Subak Tanah Yeng, Desa Sedang Kecamatan Abiansemal, Kabupaten Badung, Bali. Penelitian ini merupakan kajian yang dilakukan secara deskriptif kualitatif dengan mengemukakan permasalahan dan memberi pemecahan bagi masalah tersebut.

Tahapan penelitian dimulai dari tahap persiapan, yaitu perumusan masalah dan studi pustaka. Selanjutnya dilakukan analisis dan sintesis. Metode penelitian dilakukan dengan menganalisis sektor pertanian melalui komponen subak (Windia, 2013) dan menganalisis rencana penataan lansekap wisata melalui komponen pengembangan wisata (Inskeep, 1991). Komponen subak (Windia, 2013). Komponen subak dan komponen pengembangan wisata dianalisis dan kemudiaan disintesis berbagai potensi dan permasalahan yang timbul. Analisis dan sintesis menghasilkan aktivitas subak dan aktivitas wisatawan yang menjadi dasar bagi aktivitas agowisata subak. Selanjutnya, diperoleh konsep. Produk akhir penelitian ini berupa konsep rencana agrowisata yang berkelanjutan pada lansekap subak (Gambar 3).

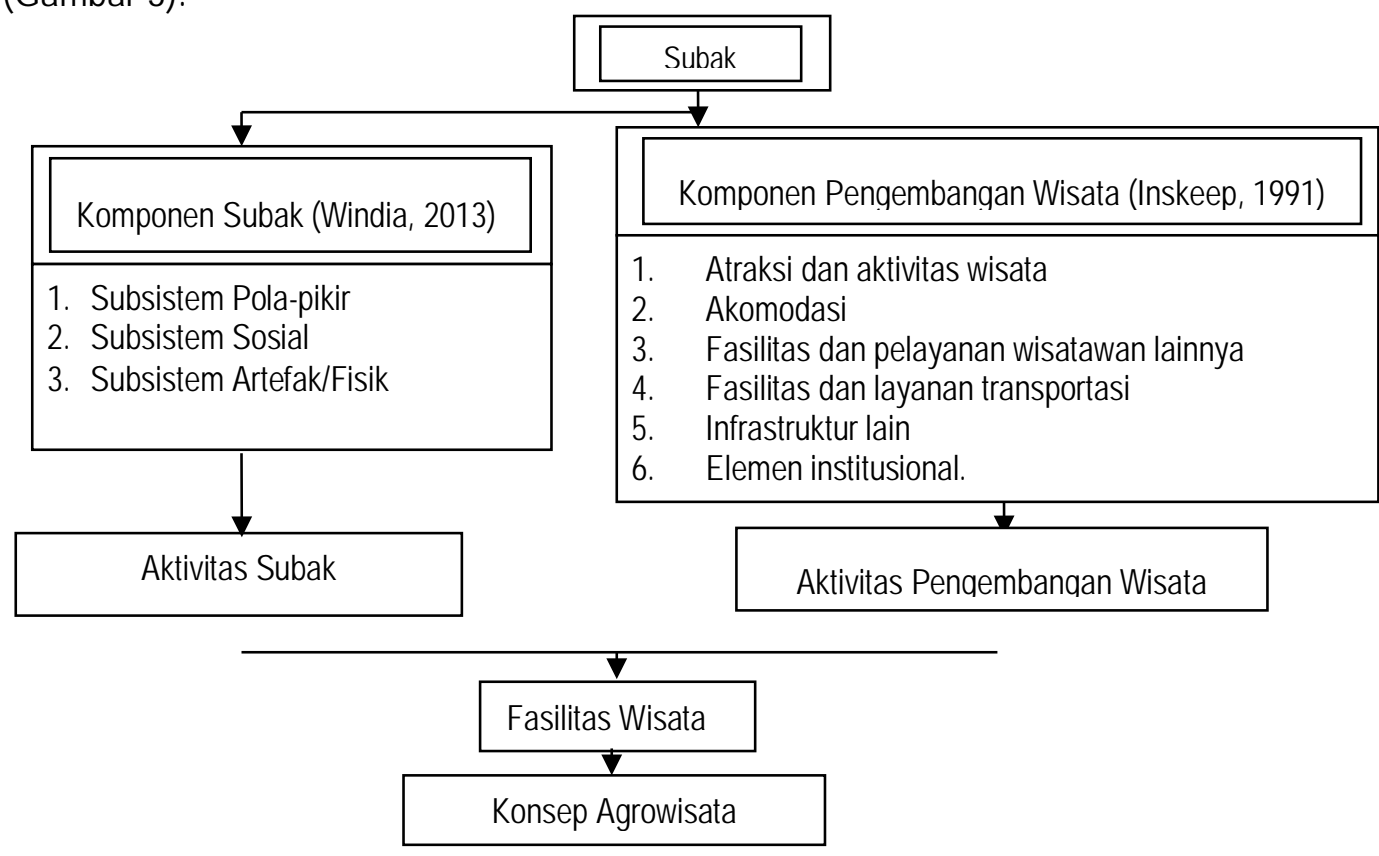

Gambar 1. Skema Tahapan Penelitian 


\section{Hasil dan Pembahasan}

\subsection{Komponen Subak}

Komponen Subak terdiri atas subsistem pola pikir, subsistem sosial dan subsistem artefak. Subsistem pola pikir merupakan nilai atau konsep dalam menjalankan sistem subak. Subsistem sosial adalah kehidupan sosial masyarakat dalam sebuah subak. Subsistem artefak adalah lingkungan sebagai tempat hidup (Windia, 2013). Ketiga subsistem ini merupakan cerminan dari filosofi hidup masyarakat Bali yaitu Tri Hita Karana dalam lingkup pertanian, khususnya subak.

Penataan kawasan pertanian di Bali, komponen subak dan filosofi Tri Hita Karana menjadi penting sebagai dasar pengembangan lansekap. Potensi-potensi yang dikaji tidak terlepas dari elemen-elemen pembentuk tapak alami, yaitu tanah, topografi, hidrologi, iklim, vegetasi, satwa, dan manusia. Apabila dikelompokkan maka akan ada faktor fisik (tanah, topografi, hidrologi, iklim, vegetasi dan satwa) dan faktor sosial-budaya (manusia). Keterkaitan antara Tri Hita Karana, Komponen Subak, dan elemen pembentuk tapak alami dapat dilihat pada tabel 1. Integrasi antara ketiga rumusan tersebut menghasilkan budaya, sosial, dan fisik yang menjadi dasar bagi pengembangan lansekap pertanian di Bali.

Tabel 1. Ketekaitan antara Tri Hita Karana, Komponen Subak, Elemen Pembentuk Tapak Alami dan integrasinya

\begin{tabular}{llll}
\hline Tri Hita Karana & Komponen Subak & $\begin{array}{c}\text { Elemen Pembentuk } \\
\text { Tapak Alami }\end{array}$ & Integrasi \\
\hline $\begin{array}{l}\text { Parahyangan } \\
\text { (Hubungan } \\
\text { manusia } \\
\text { dengan Tuhan) }\end{array}$ & Subsistem pola pikir & $\begin{array}{l}\text { Hakikat manusia } \\
\text { (makhluk berakal sehat) }\end{array}$ & Budaya \\
$\begin{array}{l}\text { Pawongan } \\
\text { (Hubungan }\end{array}$ & Subsistem sosial & $\begin{array}{l}\text { Manusia dalam } \\
\text { kesama }\end{array}$ & Sosidupan sosial \\
manusia) & & (interaksi antar sesama & \\
$\begin{array}{l}\text { Palemahan } \\
\text { (Hubungan }\end{array}$ & Subsistem artefak & manusia) & \\
Tanah, topografi, & Fisik \\
dengan & & hidrologi, iklim, vegetasi, & \\
lingkungan) & & dan satwa (interaksi & \\
\hline
\end{tabular}

Kehidupan pertanian subak di Bali diperkuat dengan aktivitas budaya berupa berbagai upacara terkait pertanian. Upacara pertanian di Bali memiliki perbedaan di beberapa daerah. Sebagai contoh upacara pertanian di Desa Sedang Kecamatan Abiansemal, Kabupaten Badung. Upacara menjadi istimewa karena merupakan kearifan lokal masyarakat Bali dalam berinteraksi dengan lingkungan. Rangkaian upacara ini dilakukan 
secara turun-temurun dan diyakini mendatangkan kebaikan bagi hasil pertaniannya. Upacara pertanian terdiri atas 21 jenis upacara dapat dilihat pada Tabel 2.

Tabel 2 Upacara Terkait Pertanian di Bali

\begin{tabular}{|c|c|c|c|}
\hline No & Nama Upacara & Waktu dan Tempat & Tujuan Upacara \\
\hline 1 & Magpag Toya & $\begin{array}{l}\text { Januari dan April } \\
\text { dilaksanakan di } \\
\text { pangulun empelan }\end{array}$ & $\begin{array}{l}\text { Untuk mendapatkan berkat dari } \\
\text { Dewi Danu agar air yang } \\
\text { dialirkan ke sawah dapat } \\
\text { menjadikan tanaman tumbuh } \\
\text { dan memberi hasil yang baik }\end{array}$ \\
\hline 2 & $\begin{array}{l}\text { Ngendag utawi } \\
\text { mungkah pretiwi }\end{array}$ & $\begin{array}{l}\text { Januari dan April } \\
\text { dilaksanakan di pintu } \\
\text { masuk air (pengalapan } \\
\text { carik) }\end{array}$ & $\begin{array}{l}\text { Untuk memohon ijin kepada } \\
\text { Dewa Surya, lbu Pertiwi, dan } \\
\text { Dewi Sri bahwa tanah akan } \\
\text { segera diolah dan kemudian } \\
\text { akan ditanami padi }\end{array}$ \\
\hline 3 & Ngurit utawi mabulih & $\begin{array}{l}\text { Januari dan April } \\
\text { dilaksanakan di petakan } \\
\text { sawah petani }\end{array}$ & $\begin{array}{l}\text { Agar Dewi Gangga dapat } \\
\text { memberikan berkatnya kepada } \\
\text { benih yang baru ditanam dan } \\
\text { benih dapat tubuh menjadi bibit } \\
\text { tanaman yang sehat serta } \\
\text { terhindar dari serangan hama } \\
\text { dan penyakit }\end{array}$ \\
\hline 4 & Ngawiwit & $\begin{array}{l}\text { Januari dan April } \\
\text { dilaksanakan di petakan } \\
\text { sawah petani }\end{array}$ & $\begin{array}{l}\text { Agar semua anggota subak } \\
\text { mulai bercocok tanam pada hari } \\
\text { yang baik dan mendapatkan } \\
\text { berkat dari Dewi Sri agar hasil } \\
\text { panen anggota subak menjadi } \\
\text { baik dan meningkat }\end{array}$ \\
\hline 5 & Neduh & $\begin{array}{l}\text { Januari dan April } \\
\text { dilaksanakan di petakan } \\
\text { sawah petani }\end{array}$ & $\begin{array}{l}\text { Sebagai perwujudan rasa } \\
\text { syukur kepada Dewi Sri dan Ibu } \\
\text { Pertiwi karena bibit yang } \\
\text { ditanam dapat tumbuh dengan } \\
\text { baikdan terbebas dari gangguan } \\
\text { hama dan penyakit }\end{array}$ \\
\hline 6 & Mabanten Tulung & $\begin{array}{l}\text { Januari dan April } \\
\text { dilaksanakan di petakan } \\
\text { sawah petani }\end{array}$ & $\begin{array}{l}\text { Agar bibit yang tumbuh dan } \\
\text { sudah memiliki anakan dapat } \\
\text { tumbuh dengan baik }\end{array}$ \\
\hline 7 & Mulanin & $\begin{array}{l}\text { Februari dan Mei } \\
\text { dilaksanakan di petakan } \\
\text { sawah petani }\end{array}$ & $\begin{array}{l}\text { Agar Sang Rare Anggon dalam } \\
\text { bentuk hama dan penyakit } \\
\text { tanaman tidak menggangu } \\
\text { pertumbuhan dari bibit padi }\end{array}$ \\
\hline 8 & Kekambuhan & $\begin{array}{l}\text { Februari dan Mei } \\
\text { dilaksanakan di petakan } \\
\text { sawah petani }\end{array}$ & $\begin{array}{l}\text { Agar Dewi Sri melindungi bibit } \\
\text { padi yang telah berusia } 42 \text { hari. }\end{array}$ \\
\hline 9 & Nipatin & $\begin{array}{l}\text { Februari dan Mei } \\
\text { dilaksanakan di petakan } \\
\text { sawah petani }\end{array}$ & $\begin{array}{l}\text { Agar Dewi Sri melindungi bibit } \\
\text { padi yang telah berusia } 42 \text { hari. }\end{array}$ \\
\hline 10 & Meiseh & Maret dan Juni & sudah \\
\hline
\end{tabular}




\begin{tabular}{|c|c|c|c|}
\hline No & Nama Upacara & Waktu dan Tempat & Tujuan Upacara \\
\hline & & $\begin{array}{l}\text { dilaksanakan di petakan } \\
\text { sawah petani }\end{array}$ & $\begin{array}{l}\text { mengembung } \\
\text { menghasilkan bulir padi yang } \\
\text { baik }\end{array}$ \\
\hline 11 & Mabyakungkung & $\begin{array}{l}\text { Maret dan Juni } \\
\text { dilaksanakan di petakan } \\
\text { sawah petani }\end{array}$ & $\begin{array}{l}\text { Agar bertemunya serbuk sari } \\
\text { dan kepala putik dapat } \\
\text { menghasilkan bulir padi yang } \\
\text { baik }\end{array}$ \\
\hline 12 & Ngusaba & $\begin{array}{l}\text { Maret dan Juni } \\
\text { dilaksanakan di Pura } \\
\text { dan petakan sawah } \\
\text { petani }\end{array}$ & $\begin{array}{l}\text { Untuk memohon perlindungan } \\
\text { kepada Dewi Sri dan Sang Rare } \\
\text { Angon agar padi yang mulai } \\
\text { menguning tidak terkena hama } \\
\text { dan penyakit tanaman. }\end{array}$ \\
\hline 13 & $\begin{array}{l}\text { Ngadegang Dewa } \\
\text { Nini }\end{array}$ & $\begin{array}{l}\text { Maret dan Juni } \\
\text { dilaksanakan di petakan } \\
\text { sawah petani }\end{array}$ & $\begin{array}{l}\text { Sebagai wujud rasa terima kasih } \\
\text { kepada Tuhan Yang Maha Esa } \\
\text { karena telah menciptakan hutan, } \\
\text { gunung, air yang dapat } \\
\text { menjadikan tanaman tumbuh } \\
\text { dengan subur dan dapat } \\
\text { memenuhi kebutuhan manusia. }\end{array}$ \\
\hline 14 & Manyi & $\begin{array}{l}\text { April dan Juli } \\
\text { dilaksanakan di petakan } \\
\text { sawah petani }\end{array}$ & $\begin{array}{l}\text { Sebagai perwujudan rasa terima } \\
\text { kasih kepada Dewi Sri yang } \\
\text { telah memberikan hasil panen } \\
\text { kepada petani sehingga panen } \\
\text { tersebut dapat memenuhi } \\
\text { kebutuhan petani }\end{array}$ \\
\hline 15 & Mendak Dewa Nini & $\begin{array}{l}\text { April dan Juli } \\
\text { dilaksanakan di Pura } \\
\text { Subak }\end{array}$ & $\begin{array}{l}\text { Sebagai perwujudan rasa terima } \\
\text { kasih karena anugrah Dewi Sri } \\
\text { berupa beras sudah sampai dan } \\
\text { dinikmati petani di rumah } \\
\text { masing-masing }\end{array}$ \\
\hline 16 & $\begin{array}{l}\text { Ngungahang Dewa } \\
\text { Nini ring lumbung }\end{array}$ & $\begin{array}{l}\text { April dan Juli } \\
\text { dilaksanakan di } \\
\text { lumbung pada rumah } \\
\text { petani }\end{array}$ & $\begin{array}{l}\text { Agar Dewi Sri sebagai Dewi } \\
\text { Kesuburan mendapat tempat } \\
\text { khusus di lumbung beras }\end{array}$ \\
\hline 17 & $\begin{array}{l}\text { Mantenin ring } \\
\text { lumbung atau } \\
\text { ngodalin jineng }\end{array}$ & $\begin{array}{l}\text { April dan Juli } \\
\text { dilaksanakan di } \\
\text { lumbung pada rumah } \\
\text { petani setelah gabah } \\
\text { disimpan di lumbung }\end{array}$ & $\begin{array}{l}\text { Sebagai perwujudan rasa terima } \\
\text { kasih atas hasil yang diperoleh }\end{array}$ \\
\hline 18 & $\begin{array}{l}\text { Nedunang pantun } \\
\text { atau nedunang sarín } \\
\text { asep }\end{array}$ & $\begin{array}{l}\text { April dan Juli } \\
\text { dilaksanakan di } \\
\text { lumbung pada rumah } \\
\text { petani }\end{array}$ & $\begin{array}{l}\text { Untuk meminta anugerah Dewi } \\
\text { Sri berupa bulir padi yang } \\
\text { kemudian akan digiling dan } \\
\text { mendapatkan beras. }\end{array}$ \\
\hline 19 & $\begin{array}{l}\text { Nyimpen beras ring } \\
\text { pulu }\end{array}$ & $\begin{array}{l}\text { April dan Juli } \\
\text { dilaksanakan di tempat } \\
\text { penyimpanan beras } \\
\text { pada rumah petani }\end{array}$ & $\begin{array}{l}\text { Agar anugerah yang diterima } \\
\text { dari Dewi Sri tidak cepat habis } \\
\text { dan dapat menjadi sumber } \\
\text { makanan keluarga }\end{array}$ \\
\hline
\end{tabular}




\begin{tabular}{|c|c|c|c|}
\hline No & Nama Upacara & Waktu dan Tempat & Tujuan Upacara \\
\hline 20 & Mralina Dewa Nini & $\begin{array}{l}\text { Tergantung kebutuhan } \\
\text { petani dilaksanakan di } \\
\text { rumah petani }\end{array}$ & $\begin{array}{l}\text { Agar Dewa-dewa yang beristana } \\
\text { di lumbung Dewi Sri dapat } \\
\text { kembali ke Khayangan }\end{array}$ \\
\hline 21 & Nangluk mrana & $\begin{array}{l}\text { Tergantung tingginya } \\
\text { serangan hama dan } \\
\text { penyakit tanaman } \\
\text { dilaksanakan di Pura } \\
\text { Ulun dan petakan } \\
\text { sawah petani }\end{array}$ & $\begin{array}{l}\text { Untuk menetralisir hama dan } \\
\text { penyakit tanaman yang } \\
\text { menyerang tanaman petani }\end{array}$ \\
\hline
\end{tabular}

Sumber: Yanti, 2016

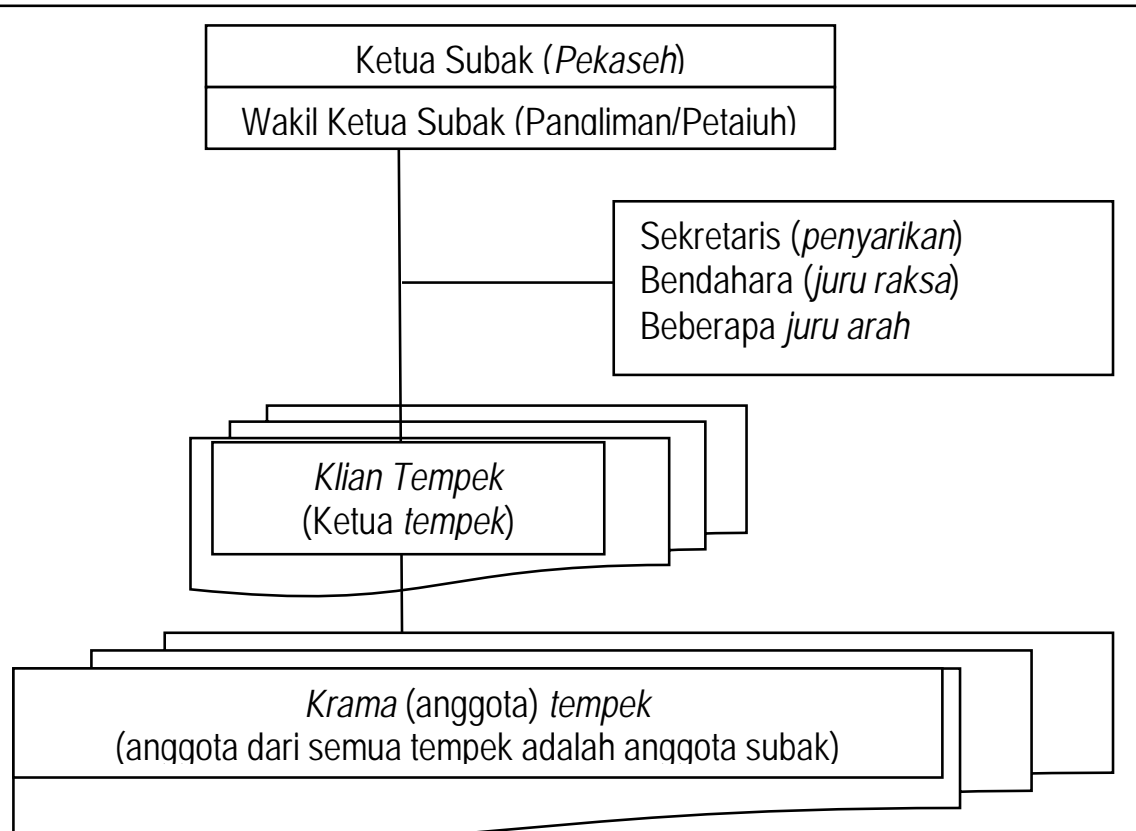

Gambar 2 Bagan Susunan Organisasi Subak yang memiliki beberapa tempek

(Sumber: Sutawan, 2008)

Masyarakat petani subak secara sosial terhimpun dalam organisasi subak. Organisasi subak merupakan suatu masyarakat hukum adat yang memiliki karakteristik sosio-agrarisreligius yang merupakan perkumpulan petani yang mengelola air irigasi di sawah (Windia, 2013). Setiap orang memiliki tugas dan tanggungjawab yang berbeda dalam subak dan diatur dalam awig-awig. Isi awig-awig subak dirumuskan bersama seluruh anggota melalui rapat subak. Awig-awig subak memuat ketentuan-ketentuan yang boleh dan tidak boleh dilakukan oleh anggota subak serta segala bentuk sanksi yang dikenakan terhadap pelanggaran yang dilakukan (Sutawan, 2008). Struktur organisasi subak ini memiliki sistem yang kuat sehingga berpotensi sebagai organisasi pengelola wisata. Secara umum, struktur organisasi subak dapat dilihat pada gambar 2 . 
Subak secara fisik terdiri atas bangunan dan jaringan irigasi, air, lahan pertanian, komoditi pertanian, bangunan tempat ibadah (Pura dan Pelinggih), dan pemandangan alam. Secara keseluruhan, fisik subak merupakan potensi bagi pengembangan wisata.

\subsection{Komponen Pengembangan Wisata}

Komponen pengembangan wisata terdiri atas atraksi dan aktivitas wisata, akomodasi, pelayanan wisatawan, layanan transportasi, infrastruktur lain, dan elemen institusional (Inskeep, 1991). Atraksi wisata di Subak merupakan bentuk daya tarik wisata yang bersumber dari subak, yaitu fisik, sosial, dan budaya yang terkandung dalam kehidupan masyarakat subak. Atrasi wisata Subak dapat berupa tradisi upacara dalam pertanian, kehidupan bermasyarakat anggota subak, bangunan irigasi, lahan pertanian, komoditi pertanian, hingga pemandangan alam sekitar. Berbagai potensi atraksi wisata ini dikembangkan sehingga menjadi daya tarik yang dapat diminati dan dinikmati wisatawan. Tahapan dalam mengembangkan atraksi wisata adalah

1) Menyesuaikan dengan konsep pengembangan wisata

2) Mempelajari obyek wisata sejenis

3) Menentukan atraksi wisata

4) Merencanakan aktivitas yang dapat dilakukan wisatawan

5) Menyediakan fasilitas penunjang atraksi wisata

6) Evaluasi terhadap atraksi wisata

7) Keberlanjutan atraksi wisata

Atraksi menentukan keberhasilan sebuah obyek wisata. Oleh karena itu, atraksi yang akan ditampilkan hendaknya mampu memenuhi kriteria berikut.

1) memuat satu pesan edukasi yang ingin disampaikan

2) Unik dan imajinatif

3) menarik dan menyenangkan untuk dilakukan

4) inovatif dan tidak membosankan

5) ada batasan waktu dan tidak melelahkan

6) disesuiakan dengan usia, pendidikan, dan budaya wisatawan

Atraksi yang ditampilkan menghadirkan reaksi wisatawan. Reaksi tersebut diolah sebagai aktivitas wisata. Atraksi yang disuguhkan bermuatan edukasi dan rekreasi. Atraksi yang edukatif artinya memberikan edukasi dengan cara yang menyenangkan. Sedangkan atraksi yang rekreatif artinya rekreasi yang dikemas dengan berbagai muatan edukasi. Contoh atraksi edukatif adalah mengajak melakukan budidaya tanaman pertanian dengan cara yang benar. Atraksi yang ditampilkan mengajak wisatawan menanam padi langsung di sawah secara berkelompok dengan diberi waktu dan penilaian terhadap masing-masing kelompok. Teknik menanam padi dilakukan dengan permainan yang menyenangkan. Atraksi rekreasi yang bermuatan edukasi contohnya memberi kesempatan wisatawan menikmati kuliner lokal yang didahului dengan membuatnya sendiri. Misalnya wisatawan diajak menikmati berbagai hidangan tahu dengan mengajak wisatawan memilih kedelai 
kualitas baik, mengolah hingga menjadi tahu, kemudian tahu diolah menjadi berbagai variasi masakan, dan dinikmati bersama. Hal terpenting adalah aktivitas wisata didukung oleh berbagai fasilitas wisata yang sesuai dan ditata dengan tepat berdasarkan kebutuhan wisatawan.

Akomodasi merupakan fasilitas wisata yang disediakan agar mampu menahan wisatawan lebih lama berada di tapak wisata. Akomodasi dapat berupa toilet, tempat makan (restoran), dan tempat penginapan (hotel). Penyediaan akomodasi sangat bergantung pada rencana aktivitas wisatawan yang dibuat oleh perencana. Semakin lama orang tinggal pada satu obyek atau destinasi wisata, maka semakin banyak akomodasi yang harus disediakan oleh perencana. Contoh akomodasi adalah tersedianya restoran yang menggunakan bahan-bahan yang berasal dari komditi pertanian yang dihasilkan sendiri. Selain memberikan kenyamanan bagi wisatawan, penyediaan restoran ini dapat mempromosikan produk pertanian yang dihasilkan. Restoran ini memberikan keuntungan bagi petani subak.

Pelayanan wisatawan adalah layanan yang diberikan melalui penyediaan fasilitas penunjang hidup yang diberikan bagi kenyamanan dan kemudahan wisatawan dalam melakukan perjalanannya. Pelayanan terhadap wisatawan meliputi penyediaan biro perjalanan untuk mempermudah akses wisatawan menuju obyek wisata atau destinasi wisata lainnya, layanan ibadah agar wisatawan memperoleh kenyamanan rohani, layanan kesehatan ditujukan untuk memberikan pertolongan pertama pada kesehatan wisatawan sebelum ditangani lebih lanjut pada lokasi layanan kesehatan lanjutan, layanan Keamanan yang memberikan rasa aman bagi diri dan segala harta benda wisatawan, bank atau layanan yang mendukung aktivitas ekonomi untuk memudahkan wisatawan dalam melakukan transaksi ekonomi, dan hiburan untuk mengisi waktu luang wisatawan dalam perjalanan wisatanya.

Sebuah perjalanan wisata selalu menginginkan dapat mengunjungi banyak obyek wisata dan merasakan berbagai aktivitas wisata. oleh karena itu, dibutuhkan layanan transportasi yang memadai. Dalam penataan tapak agrowisata subak, penyediaan layanan transportasi membutuhkan kerjasama dengan pemerintah. Layanan transportasi yang disediakan meliputi

- Akses jalan menuju tapak wisata

- Akses jalan di dalam tapak wisata

- Alat transportasi menuju tapak wisata (publik \& pribadi)

- Alat transportasi di dalam lokasi

- Jalur sirkulasi wisata yang teratur, terarah, dan menyenangkan

- Parkir kendaraan

Secara terencana infrastruktur lain dapat dibangun dengan bantuan Pemerintah. Infrastruktur tersebut sangat penting bagi kebutuhan dasar dalam tapak. meliputi

- Suplai dan saluran air bersih

- Saluran pembuangan dan sarana pengolahan limbah

- Suplai dan aliran listrik

- Tempat sampah dan lokasi pembuangan atau pengolahan sampah 
- Sarana informasi dan komunikasi

Penyediaan infrastruktur lain mensuplai kebutuhan dasar manusia yang tidak dapat dihindari. Dalam agrowisata subak, program infrastruktur desa perlu dikuatkan agar desa emperoleh infrastruktur dasar yang sama dengan kota, sehingga perekonomian desa dapat maju dengan cepat.

Elemen institusional merupakan kegiatan mempersiapkan masyarakat lokal sebagai sumber daya wisata sehingga kegiatan wisata dapat berdampak bagi peningkatan kesejahteraan masyarakat. Keterlibatan menimbulkan rasa memiliki oleh masyarakat sehingga masyarakat ikut berperan aktif dalam menjaga keberlangsungan kegiatan wisata dan kelestarian tapak wisata. elemen institusional meliputi :

- Pendidikan dan pelatihan bagi pelaku wisata

- Promosi dan strategi pemasaran

- Organisasi pengelola wisata

- Regulasi dan kebijakan

- Program ekonomi dan evaluasi program

- Program sosial dan evaluasi program

- Program pelestarian/perlindungan lingkungan dan evaluasi program

- Program budaya dan evaluasi program

\subsection{Pengembangan Agrowisata}

Subak sebagai agrowisata tidak dapat terlepas dari sistem pertanian dan sistem wisata yang terintegrasi dan harmonis. Sistem subak sebagai lansekap pertanian di Bali dalam kaitannya dengan wisata saling bersinergi dan terintegrasi. Keterkaitan antara keduanya dapat dilihat dalam tabel 3.

Tabel 3 Keterkaitan Lansekap Pertanian dan Komponen Wisata

\begin{tabular}{lll}
\hline Lansekap Pertanian & Komponen Wisata & Integrasi \\
\hline Budaya & Atraksi & Atraksi wisata \\
Sosial & Elemen institusional & Pengelola wisata \\
Fisik & Atraksi, akomodasi, & Atraksi dan fasilitas wisata \\
& pelayanan wisata, layanan & \\
& transportasi, infrastruktur & \\
& lain & \\
\hline
\end{tabular}

\subsection{Konsep Pengembangan Agrowisata}

Konsep dasar dalam pengembangan agrowisata subak ditujukan untuk menjaga eksistensi subak. Wisatawan berbaur dengan masyarakat lokal yang secara tidak langsung memberikan pengetahuan tentang subak. Agrowisata subak mengandung edukasi, rekreasi, dan pelestarian kawasan pertanian, sehingga masyarakat lokal dan wisatawan memahami arti penting subak bagi kelangsungan hidup manusia. Bagan konsep dasar dapat dilihat pada gambar 3. 


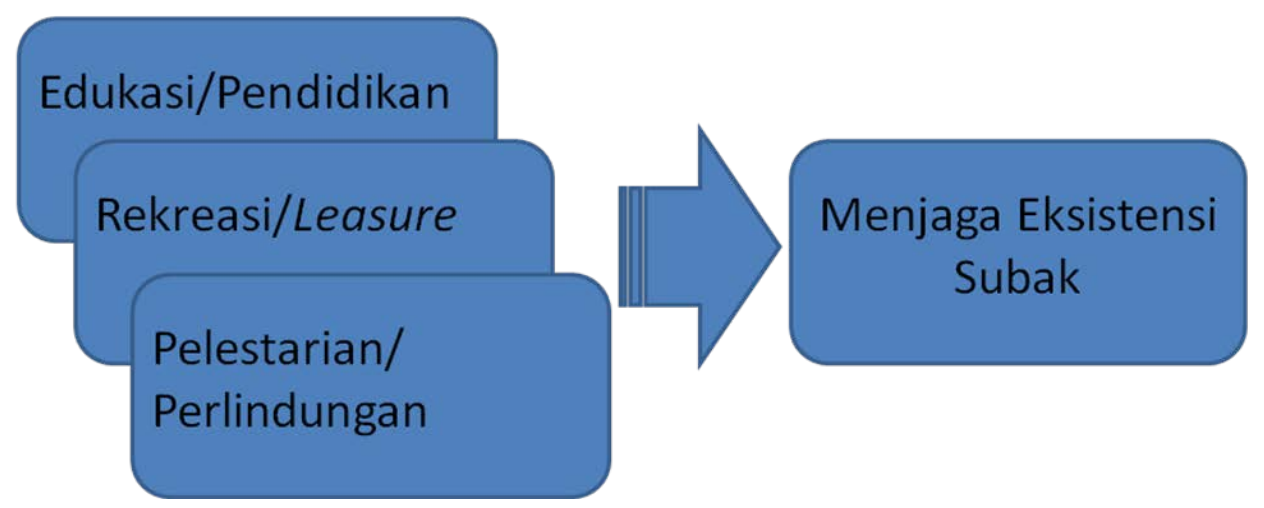

Gambar 3. Konsep Dasar Agrowisata Subak

Perlu dipahami bersama, bahwa agrowisata subak merupakan wisata terbatas. Keterkenalan obyek agrowisata subak bukan didasarkan atas kuantitas pengunjung melainkan kualitas kunjungan. Agrowisata merupakan jenis wisata minat khusus yang memiliki pesan kuat terhadap edukasi dan pelestarian. Oleh karena itu, pengembangan agrowisata subak diarahkan pada pengembangan potensi kawasan sebagai atraksi wisata.

Konsep pengembangan agrowisata subak lebih diarahkan pada penataan kawasan agar memberikan kenyamanan bagi wisatawan untuk beraktivitas tanpa mengganggu aktivitas petani. Berbagai kegiatan yang dikemas tidaklah sengaja dibuat khusus bagi wisatawan, melainkan berdasarkan kondisi yang ada di lapangan saat itu. Hal ini menjadi dasar dibuatnya konsep tata ruang, tata sirkulasi, dan tata hijau.

1. Konsep tata ruang

Penataan ruang dibuat dengan memperhatikan atraksi wisata. Atraksi wisata tersebut dapat bersumber dari aktivitas petani di lahan pertanian (persiapan lahan, penanaman, pemeliharaan, panen, dan sebagainya), aktivitas masyarakat petani (gotong-royong, kegiatan pasca panen, penjualan hasil panen, kuliner, dan sebagainya), aktivitas penunjang kegiatan pertanian (ritual keagamaan, ritual budaya, dan sebagainya). Aktivitas ini dapat berjalan dengan baik bila didukung dengan fasilitas wisata, sehingga wisatawan merasa nyaman.

2. Konsep tata sirkulasi

Penataan sirkulasi dikonsepkan untuk memberikan kesempatan bagi wisatawan lebih dekat dengan pertanian. Interaksi langsung dengan lahan pertanian dan komoditi pertanian memberikan pengalaman tersendiri bagi wisatawan. Untuk itu, konsep sirkulasi diarahkan untuk mendukung kegiatan wisatawan menyatu dengan petani. Jalur dibuat untuk dapat sedekat ungkin dengan komoditi pertanian dan terjun langsung pada aktivitas bertani.

\section{Konsep tata hijau}

Penataan hijauan tidak secara spesifik dilakukan. Penataan vegetasi dilakukan hanya pada welcome area sebagai daya tarik bagi pengunjung dengan menggunakan tanaman peneduh dan tanaman estetik. Penataan pada ruang aktivitas hanya dieruntukkan bagi kenyamanan wisatawan seperti adanya tanaman peneduh. Secara 
keseluruhan, lahan pertanian sudah estetik sehingga tidak lagi memerukan penataan hijauan. Tata hijau diarahkan untuk menunjang fungsi ruang dan fungsi sirkulasi.

\subsection{Rencana Lansekap Agrowisata Berkelanjutan}

Rencana Lansekap Agrowisata Berkelanjutan disusun dengan memperhatikan:

1) Pengelola wisata dibentuk oleh masyarakat lokal dengan tujuan peningkatan kesejahteraan bersama

2) Pengelola wisata dan masyarakat memperoleh arahan, pendampingan, pendidikan dan pelatihan dari pihak terkait dalam menyelenggarakan wisata

3) Pengembangan wisata didasarkan pada daya dukung kawasan dan bukan pada target jumlah pengunjung

4) Atraksi wisata memiliki pesan positif, serta kreatif \& inovatif

5) Penyediaan sarana dan prasarana penunjang wisata didasarkan atas kebutuhan wisatawan agar memberi kenyamanan bagi wisatawan

6) Aturan, regulasi, dan kebijakan terkait subak mendukung eksistensi subak dan konservasi lahan pertanian

7) Melakukan monitoring dan evaluasi terhadap penyelenggaraan wisata

\section{Simpulan}

Pengembangan kawasan pertanian sebagai agrowisata memberikan manfaat ekonomi bagi masyarakat. Subak sebagai organisasi masyarakat pertanian dikembangkan sebagai pengelola wisata berbasis masyarakat, sehingga mampu mensejahterakan anggotanya. Manfaat ekonomi yang mensejahterakan anggota subak ini diharapkan dapat mencegah terjadinya alih fungsi lahan dan mempertahankan eksistensi subak. Eksistensi subak harus didukung oleh regulasi dan kebijakan yang disusun oleh kelompok masyarakat dan pemerintah agar dapat berpihak kepada petani.

\section{Daftar Pustaka}

Inskeep E. 1991. Tourism Planning. An Integrated and Sustainable Development Approach. NVR Tourism and Commercial Recreation Series. New York: Van Nostrand Reinhold.

Sutawan N. 2008. Organisasi dan Manajemen Subak di Bali. Denpasar: Pustaka Bali Post.

Windia W, Wiguna WAA. 2013. Subak Warisan Budaya Dunia. Denpasar: Udayana UnivErsity Press.

Yanti NKD. 2016. Studi Potensi Subak Tanah Yeng sebagai Kawasan Agrowisata di Desa Sedang, Kecamatan Abiansemal, Kabupaten Badung [Skripsi]. Tidak dipublikasikan. Denpasar: Fakultas Pertanian Universitas Udayana. 